NGUYỄN THI! MỸ Linh

DOI: 10.15170/DikE.2021.05.01.10

$\mathrm{PhD}$ student

PTE ÁJK

Lecturer

Can Tho University Vietnam

\title{
Marital Agreements in Vietnam from 1858 until Now
}

The institution of prenuptial agreement is a founder of contractual matrimonial property regime. The possibility of concluding a marriage contract contributes to ensuring the equal rights of the spouses, as they are free to agree on their pre-marital property. Recognizing the necessity of the contractual freedom in family law, the 2014 Act on Marriage and Family of Vietnam allows couples to choose between the statutory property regime and the agreed property regime. This article presents the history of the institution of marriage agreement in Vietnam, also with regard to the development of law in European countries.

Keywords: prenuptial agreement, matrimonial property law, colonial French law, Vietnamese law

\section{Historical development of the contractual matrimonial property regime in Vietnam}

Agreed property regime has existed in the legislative history of modern Vietnam with the name marital contract or marital indenture. However, this term no longer appears in the Vietnamese Act on Marriage and Family in 1959, 1986, 2000 until the 2014 Act on Marriage and Family was enacted under the name of 'an agreed property regime'.

When France invaded Vietnam in 1858, they applied the provisions of the Civil Code of France (Napoleonic Code in 1804) to Vietnam to manage and easily govern as their own. In fact, France divided Vietnam into three regions for easy governance and management. So, at this moment, Vietnam has three sets of laws in the North, the middle, and the South. In the south, France introduced the Civil Code in 1883 (as known as Précis de 1883) and applied it in the south and the three big cities of Hanoi, Hai Phong and Da Nang. In addition, France issued the 1931 Northern Civil Code ${ }^{1}$ in the North and the 1936 Central Civil Code $^{2}$ which was applied in the Middle. $^{3}$

According to the 1931 Northern Civil Code, there had been a progressive regulation on contractual property between husband and wife. In terms of property, the law was only applicable to the property of the husband and wife when they had no marriage contract. If the marriage contract was not contrary to the fine customs and the interests of the husband, it was

\footnotetext{
1 This law was issued on March 30 th 1931 and applied from July 1 ${ }^{\text {st }}, 1931$ in the North of Vietnam. See HÀ NHU, Chế độ hôn sản pháp định trong luật Việt Nam 39.

2 This law was issued on July $13^{\text {th }} 1936$ and applied to the Center of Vietnam.

${ }^{3}$ See NGuren Thi My, The Impact of the French Colonial Law on the Development of Matrimonial Property Law in Vietnam.
} 
advocated in the union. ${ }^{4}$ The 1936 Central Civil Code in the Middle of Vietnam stated: If the busband and the wife had no agreement, the property of the husband and wife shall be incorporated into the community property, that is the gains from the property of the husband and wife united into one. ${ }^{5}$ In the South, the 1883 Southern Civil Code, however, did not provide specific information about the matrimonial property regime. ${ }^{6}$

The North of Vietnam regained independence under the leadership of the Communist Party in 1945. This region built a civil and family law system that differed significantly from the Codes drawn up during the French colonial period. In 1959, North Vietnam promulgated the Act of Marriage and Family in $1959^{7}$ issued by the State and it confirmed the nature of socialist law. The 1959 Marriage and Family Act only allowed common property between husband and wife, which was the statutory property law. ${ }^{8}$ After 1954, the USA replaced the French colonialists in the war of aggression in the South. The Civil Code of $1972^{9}$ stipulated that spouses can freely make marriage contracts at their will, but not against the public order and fine customs ${ }^{10}$. In addition, the law provided that statutory property regimes were applicable only when spouses had no agreement to establish a marriage contract. ${ }^{11}$ From 1975 to 2018, Vietnam has been undergoing three major regulations on property regime between husband and wife. Specifically, the 1986 Act on Marriage and Family, ${ }^{12}$ the 2000 Act on Marriage and Family ${ }^{13}$ and the 2014 Act on Marriage and Family. ${ }^{14}$ The marriage and family issues were regulated as a separate law that was independent from Vietnam's Civil Code since the 1959 Act on Marriage and Family.

However, there was a major limitation in the $1959,{ }^{15} 1986$ and 2000 Act on Marriage and Family that they did not regulate the prenuptial agreement property. Specifically, these laws only recognized the statutory property regime which consisted of both common and separate properties. In contrast, the 2014 Act on Marriage and Family which has been in effect since January 1, 2015 recognises the prenuptial agreement as one of the matrimonial property regimes. Article 28 of the 2014 Act on Marriage and Family noted Husband and wife have the right to choose between the statutory property regime and the agreed property regime. The statutory property regime of husband and

\footnotetext{
4 Article 104 of the 1931 Northern Civil Law. In addition, Bui Minh Hong also mentioned in detail the marriage contract in the law at this time. At the same time, the author compared French law. See: BùI MINH, Chế dộ tài sản theo thỏa thuận của vợ chồng liên hệ từ pháp luật nước ngoài đến pháp luật Việt Nam.

5 Article 105 The 1936 Central Civil Code.

6 See NGuYen Thi My, The Impact of the French Colonial Law on the Development of Matrimonial Property Law in Vietnam. A comparison between the original 1804 French Civil Code, and the 1883, 1931, and 1936 Vietnamese Civil Codes in perspective of the marital agreement is clarified in this study.

${ }^{7}$ Law No. 2/1959/QH, dated December 29, 1959 of The National Assembly on Marriage and Family which was applied to The North of Vietnam.

${ }^{8}$ Article 15 in The Marriage and Family Law 1959 (Law No. 2/1959/QH, dated December 29, 1959 of The National Assembly on Marriage and Family which was applied to The North of Vietnam).

9 Pursuant to Law No. 028 T'T / SLU dated December 20, 1972 by the president of the Democratic Republic of Vietnam.

10 Article 144 the Civil Code of 1972.

11 Article 45 The Family Law in the south and Article 145 the Civil Code of 1972.

${ }^{12}$ Law No. 21-LCT/HDNN7, dated December 29, 1986 of The National Assembly on Marriage and Family.

${ }^{13}$ Law No. 22/2000/QH10 dated June 109, 2000 of The National Assembly on Marriage and Family.

${ }^{14}$ Law No. 52/2014/QH13 dated June 19, 2014 of The National Assembly on Marriage and Family, gazette number 52/2014/QH13.

15 The Family Law in the North was issued and recognized by Socialist Republic of Vietnam. Law No. 2/1959/QH, dated December 29, 1959 of The National Assembly on Marriage and Family which was applied to The North of Vietnam.
} 
wife complies with Articles 33 to 46 and from Article 59 to Article 64; the agreed property regime between busband and wife complies with Articles 47 to 50 and 59'. Thus, the Act 2014 on Marriage and Family stipulates that a husband and wife can choose either the statutory property regime or the agreed property regime. Recognition of the property regime according to the agreement aims to create conditions for the husband and wife to practice the marriage regime suitable to their economic conditions. Thus, the 2014 Act on Marriage and Family creates more conditions for husband and wife in choosing which property regime is the most suitable for them.

Although it is regulated in current law, the prenuptial agreement is rarely chosen by couples to establish in Vietnam and around the world. For example, according to a 1993 US survey, legal commentators and practitioners estimate that only 5-10\% of the population enter into prenuptial agreements, and one study suggests that only $1.5 \%$ of marriage license applicants would consider entering into such agreements. ${ }^{16}$ This section suggests that the relative scarcity of prenuptial agreements might be explained by two phenomena: '1) couples may systematically underestimate the expected benefits of premarital agreements; and 2) couples may be hesitant to discuss a prenuptial agreement because each person might believe that initiating the conversation would signal uncertainty about the success of the marriage and would conflict with the romance of courtship.'

\section{The establishment of matrimonial agreement}

First, a marital agreement must be signed before the spouses register their marriage. The agreement before marriage is considered a basic feature to distinguish between the agreed property regime and the statutory property regime. Regarding the French Civil Code, for a valid marital contract, couples must comply with clearly stated procedural requirements through the role of the notary. The marriage certificate will be clearly mentioned the spouses' agreement and the notary will note the couple's compromise on the face of marriage certificate. There would be further registrations, once one of the spouses is a merchant according to French law. The spouses have to inform third parties about their agreement, if not, the contract will be invalid to third parties, except for those third parties who have known the contract's existence and terms. The spouses must go through the Court's procedure, if they have further amendment or modification of the contract to ensure the interest of the family and third parties. The court will determine the later agreement to make sure that it complies with the relevant laws and interest of family members, other parties. ${ }^{17}$

Second, the prenuptial agreement regime is in the form of notarized or authenticated documents. The notarized or authenticated written agreement is a common written agreement with certification procedures at a notary public agency or certification at a competent state agency. The form of notarization or authentication agreement will have a much stronger legal value than conventional documents. In terms of evidence, the notarized or authenticated agreement will have more reliability, so in the current Act on Marriage and Family, the provisions of the husband and wife's agreement must be notarized or authenticated to ensure safety, limit the arising of conflicts and disputes between husband and wife.

\footnotetext{
${ }^{16}$ See MAHAR, Why are there so few prenuptial agreements?

${ }^{17}$ See Brown, The Enforcement of Marital Contracts in the United States, Great Britain, France and Quebec.
} 
Third, the matrimonial agreement property comes into effect at the date of marriage registration. In addition, husband and wife can agree to amend, supplement and terminate the property regime according to the agreement. During the marriage period, husband and wife may amend and supplement part or all of the contents of the signed agreement on the property regime before the marriage, if they agree to chance or terminate the prenuptial agreement. Once the prenuptial agreement is terminated based on the couple's compromise, the statutory property regime can be applied. However, the amendment and supplementation must not violate the provisions of the current Act on Marriage and Family which stipulate that the agreement is invalid. In addition, this amendment and supplement agreement must still be notarized or authenticated to take effect.

\section{Basic contents of an agreement on the matrimonial property regime}

The spouses are free to settle matters related to property. However, when settled, the parties must also ensure that the contents of their agreement meet the requirements of the basic matrimonial property regulations of the 2014 Act on Marriage and Family ${ }^{18}$. If the agreement lacks one of the basic contents leading to invalidity, statutory property law will apply instead. Accordingly, the spouses can agree on property in many different ways.

Having both common property and private property, if the couple choose this option, the property of the spouses include three blocks of property including the common property, wife's separate property, husband's separate property. Husband and wife may determine that their possessions before or during the marriage are common property, and with respect to separate property that is personal effects and articles of personal use and any property acquired by gift, or inheritance, individually. It can be said that with this choice, it does not lessen the common property community of the husband and wife - the foundation of the marriage. It also creates favourable conditions for them to take the initiative in disposing of their own property and can prevent the cases of marriage with a dishonest purpose of a spouse targeting its separate assets. In addition, the determination of common and separate property is enabling husband and wife to be responsible for the stability and development of the family. If spouses feel that such an agreement is incompatible with the marriage's goal, which is a community of responsibility, joint strength, shared will, they have to decide jointly on their property, they can choose the other two options mentioned below.

Having only common property, there is no private property between spouses, but all property acquired by the husband or wife during marriage is common property. ${ }^{19}$ Thus, during the marriage period, only one property exists, which is the common property, the property created by husband and wife before marriage or during the marriage period. In this case their belongings are common property of husband and wife. When they choose to have only this one common property, the couple's interests are influenced by the community in marriage and the interests of the family come first. During the marriage period, a common ownership relationship between spouses always exists. Thus, this option does not recognize the right to have private property, but only acknowledges joint ownership. Perhaps this provision is derived from the

\footnotetext{
${ }^{18}$ Mainly mentioned in Articles 29, 30, 31, 32 of the 2014 Act on Marriage and Family.

${ }^{19}$ Clause b Article 15 of Decree No. 126/2014/ND-CP dated December 31, 2014 by The Vietnam's Government. This Decree is detailing a number of Articles and Measures for implementation of the Act on Marriage and Family 2014.
} 
concept of common needs, the common interests of the family are supreme, and the property of the husband and wife is recognized and protected by law for that same purpose. This model, however, has drawbacks at some points as if a party wants to conduct business or invest separately, and does not want to affect the common property, he/she must take the common property to invest in his/her own business due to clacking of separate property based on their prenuptial agreement. If this type of agreement is still not meeting with the demand of spouses, they may choose the other mentioned below which just has only separate property during their marriage life.

Having only spouse' separate property, there is no common property between husband and wife, but all property acquired by them before and during the marriage is privately possession. ${ }^{20}$ Unlike the second option, with this option, the husband and wife will have to determine the amount of property during the marriage period, which does not have common property, but only two separate property blocks, which are the property of the wife and husband. Accordingly, each spouse is free to manage and dispose of their assets and income after marriage. With this option, husband and wife will have a great deal of autonomy in the matter of disposing of their property. This provision is probably suitable for couples conducting production and business jobs where they need to avoid possible risks to their families, caused by business failures. In practical sphere, Vietnamese couples seem not to choose this model due to the influences of the long-standing customs and concept of the Vietnamese valuing marriage as a bonding place between family members. The fact that one party proposes to establish a separate property before marriage causes self-esteem for the other party because of pre-marriage separation. So, although it is officially mentioned in the law, the parties are still quite cautious about this method before getting married. In fact, this method is chosen when a party has many properties before marriage and the choice of agreement to establish a separate property regime before marriage will help their wealth to be preserved.

Regarding sphere of agreement influence, the rights and obligations of the couple also rule out that concern about management and disposal to their property, transactions and the family's essential needs. On the basis of determining the content of property in the previous agreement, husband and wife agree on the rights of each party to common property, private property as well as separate obligations, common obligations on the two parties' property must bear and the family's essential needs, which will be guaranteed by common property or private property. Ensuring the conditions to meet the family's essential needs is the spouses' obligation. In cases where they agree that the property to ensure the family's essential needs is common property but if it is not enough, they need to agree on the amount of contribution of their own property and common property to ensure the essential needs for the family.

Concerning the conditions, procedures and principles of property division upon termination of the prenuptial agreement regime, these issues should be clearly mentioned as the very first step of the compromise. The agreement to establish the matrimonial property regime is made before the marriage and takes effect at the date of the couple carry out the marriage registration procedures according to the order, conditions and provisions of the law. Stemming

\footnotetext{
20 Article 15 of Decree No. 126/2014/ND-CP dated December 31, 2014 by The Vietnamese Government. This Decree is detailing a number of Articles and Measures for the implementation of the Act on Marriage and Family 2014.
} 
from the needs of each party, spouses can agree on the conditions for the termination of the property regime according to the agreement and determine in which cases does spouses have the right to demand to end this property regime. Once they agree on the termination of the property regime, the property will be divided between them according to the procedure (agreement or request to the competent authority to settle) based on the agreement of the couple and the principle of property division upon termination. In principle, property can be divided according to the way of common property division during the marriage period or according to other division principles, which are agreed upon by the husband and wife. When a dispute occurs, the settlement of the dispute is applied according to the agreement of the husband and wife.

For example, in case of applying the agreed matrimonial property regime, the settlement of property upon divorce must comply with such agreement. In case of the agreement is insufficient or unclear, the settlement must comply with corresponding provisions of Clauses 2 , 3, 4 and s Article 5 and Articles 60, 61, 62, 63 and 64 of the 2014 Act on Marriage and Family which has the same rules as the spouse applying the statutory property regime. Regarding common property in marital agreement regime, it shall be divided into two, taking into account the following factors: 1) Circumstances of the family, husband and wife; 2) Each spouse's contributions to the creation, maintenance and development of common property. The housework done in the family by a spouse shall be regarded as income-generating labour; 3) Protecting the legitimate interests of each spouse in their production, business and career activities to create conditions for them to continue working to generate incomes; 4) Each spouse's faults in the infringement of spousal rights and obligations. Common property of husband and wife shall be divided in kind, if impossible to be divided in kind, common property shall be divided based on its value. The partner who receives the property in kind with a value bigger than the portion he/she is entitled to receive shall pay the value difference to the other. Separate property of a spouse shall be under his/her ownership, except for separate property already merged into common property in accordance with the 2014 Act on Marriage and Family. A spouse who requests division of separate property which has been merged into or mixed with common property shall be paid for the value of his/her property contributed to common property, unless otherwise agreed by husband and wife. The lawful rights and interests of the wife, minor children or adult children who have lost their civil act capacity or have no working capacity and no property to support them shall be protected.

However, the establishment of a marriage contract must be established prior to marriage and not after it. During the marriage period, couples are entitled to switch from a marriage contract to a statutory marriage property. Conversely, couples who are applying a statutory property regime cannot be transferred to a marriage contract after marriage. Explaining this rule, lawmakers argued that the choice of the statutory property regime was that spouses could still agree to divide their common property into separate property or merge separate property into common property during the marriage. In addition, this contributes to the difference with the contract of marriage - the agreement model must be established before marriage and cannot be established after marriage.

Compared to the Hungarian legislation on marriage, there are two property regimes which are the statutory property regime and the matrimonial agreement property regime. With respect to the statutory property regime, there are two main types of property that are community 
property and separate property. As for the marriage contract, couples may choose to sign premarital agreement (also known as ante-nuptial agreement) or post marital agreement which take effect from the time establishing agreements. ${ }^{21}$ Unlike Vietnam's law, Hungarian law does not limit the time of establishing a marriage contract which can only be signed before getting married. This is the regulation that Vietnamese family law should learn from the Hungarian law. ${ }^{22}$ Many countries in Europe consider pre-marriage and post-marriage agreements indistinguishable, applying the same legal standard to the spouse whether the compromise was made before or after the marriage. In Germany, for example, spouses can choose from contractual property arrangement recognised in the German Civil Code, but agreements between spouses must not result in unacceptably inconsistent burden sharing. In France, by contrast, spouses are prohibited from changing their property regime until two years have elapsed according to the French Civil Code to protect the interest of the family. Some other European states limit the spouse's agreement at the time the divorce relating to maintenance or refuse to recognise the waiver of future spouses of maintenance. Taking German for instance, it allows spouses to change the default rules to keep and exclude post-divorce alimony in its entirety. Concerning the formation of marriage contracts, they require the agreement must be done in the form of notary which serves as an impartial advisors being trained and experienced in many European nations. ${ }^{23}$

In addition to the abovementioned main contents, in the content of the agreement, the couple can agree on other contents such as the support of parents and children related to the matrimonial property regime based on the needs and circumstances of each party. The general principle of the matrimonial property regime stipulates that husband and wife are equal in terms of their rights and obligations in the creation, possession, use and disposition of common property and do not differentiate between family workers and income workers. The spouses have to ensure the conditions to meet the family's essential needs, if the performance of property rights and obligations of spouse infringes upon the legitimate rights and interests of each spouse, their family and other persons, compensation must be made.

\section{Modification and invalidation issues of an agreed property regime 4.1. Modification of the prenuptial agreement}

Pursuant to Article 17 of Decree No. 126/2014/ND-CP detailing a number of articles and measures to implement the Act on Marriage and Family and Article 49 of the 2014 Act on Marriage and Family, the spouses have the right to reach an agreement, amend, supplement a part or all of the contents of the prenuptial agreement property regime or apply the statutory property regime according to law. Property rights and obligations arising before the effective date of the amendment and supplement of the prenuptial agreement property regime are still legally valid, unless otherwise agreed by the parties. On the other hand, when performing transactions with a third person related to the agreed property, the spouses are obliged to provide the third person with information on agreements related to that property.

\footnotetext{
${ }^{21}$ Article 4:63 in Hungary Code of 2013 - Book Four (Family Law) prescribes that '(1) The function of the marriage contract is to permit the parties to the marriage or the spouses to define a property regime - in lien of marital community of property - with a view to governing their property relationships during the marriage from the time specified in the agreement....

22 See NGuYen Thi Mr, The Development of Matrimonial Property Law in Vietnam.

23 ATWOOD, Marital Contracts and the Meaning of Marriage.
} 
Regarding the time of modification, during the marriage period, the couple have the right to agree to amend or supplement a part or all of the contents of the property regime or apply the statutory property regime. Although the marriage agreement is highly stable, the law still allows it to be amended even after they get married to ensure rights related to the property of the couple, ensuring freedom. The husband and wife's agreement is protected by the law.

In terms of form, the amendment and supplementation of the agreement as well as the new establishment of the agreement content are not only related to the rights and obligations of the spouses but also to the interests of a third person. Therefore, amending and supplementing the content of the prenuptial agreement property regime, they must follow the strict form as well which is must be done in the form of notarized or authenticated documents as prescribed by law. The amendment and supplementation take effect from the date of the notarization or authentication.

Modification and supplementation of a part or the whole of the agreement does not terminate the agreement on the matrimonial property regime, there will only be changes in some contents of previous agreements. When a modified or supplemented agreement on the prenuptial agreement regime is established, the spouses need to provide third parties with relevant information in case of having a transaction with a third person. If a husband or wife violates this obligation, the interests of a third person will still be protected by law according to the provisions of the Civil Code. This regulation aims to avoid the situation in which the couple takes advantage of the modification and supplementation of the content of the agreement on the matrimonial property regime to avoid the completion of civil obligations. If the agreement is amended and supplemented, property rights and obligations arising before the effective date of the modification or supplementation are still legally valid, except that the party has another agreement. Thus, whether an agreement on the matrimonial property regime is newly established or amended, supplemented, it only changes the rights and obligations between husband and wife according to the agreement, without changing the rights as well as property obligations of the spouse to the relevant third party.

\subsection{Invalidation of the prenuptial agreement}

According to Article 50 of the Act on Marriage and Family 2014 and Article 6 of Joint Circular 01/2016/TTLT-TANDTC-VKSNDTC-BTP, the agreement on the matrimonial property regime can be declared invalid by the Court. Once an agreement on the prenuptial agreement regime is declared totally invalid by the Court, the statutory property regime shall be applied. If the prenuptial agreement property is declared to be partially invalid, the contents that are not invalid will still apply. For the invalid content, the statutory provisions on the matrimonial property regime shall be applied. The prenuptial agreement property is declared invalid when violating one of the following provisions:

Firstly, the agreement is defined invalid, if it is not comply with the conditions of the validity of the transaction specified in the Civil Code and other relevant laws such as the legal capacity of husband and wife, agreement content, violating prohibitions, or violating social ethics. If the spouses, for example, are not of marriage age at the time of making the agreement or lose the civil act capacity at the time of the agreement, the agreement will be declared invalid. The 
agreement will be also declared void, if at the time of establishment, one or both parties are in a state of involuntary (threatened, deceived, and mistaken). Thus, o based on the provisions, if the marriage is declared void due to violation of the age condition or the condition of voluntariness, the agreement on the property regime between husband and wife is also declared invalid.

Second, it breaches one of the provisions of Articles 29, 30, 31, and 34 of the 2014 Act on Marriage and Family because of imbalance in establishing property rights; guaranteeing essential needs of the family; or breaking transaction rules regarding the house being the only residence of spouses. It may also be void as the content of the agreement seriously violates the rights and interests of parents, children and other family members. Contents of an agreement on the matrimonial property regime are invalidated due to a serious violation of the right to support, the right to inheritance and other legitimate rights and interests of parents, children and other members. If the agreement evades the supported obligation specified in Articles 110 to 115 of the Law on Family and Marriage or obstructs the right of inheritance of independent heirs, it will be worthless. For example, the father has an adult child but cannot work. After that, the father gets married to the step mother and they sign a property agreement regime, in which the entire father's assets will be inherited by the step mother when the father dies. In this case, the content of the agreement on the property regime between the couple will be invalidated with respect to the part of property of the father, that the adult child is inherits in accordance with the legal provisions.$^{24}$ Concerning the above provisions, the law allows husband and wife to freely agree to dispose of their property but still have to ensure the property obligations that husband and wife have to bear with a third person and members of the family. This provision also contributes to preventing agreements established by husband and wife for dishonest purposes, avoiding the performance of civil obligations, affecting the legitimate rights and interests of related persons; contribute to protecting the legitimate rights recognized by law of parents, children and other family members.

Third, it breaches the regulations on transactions with a faithfull third person relating to bank accounts, securities accounts and other real estate that do not require registration of ownership, right to use by law. For example, before marriage, the spouses have a written agreement on the establishment of the property regime, in a document identifying land use rights as private property of the husband before the marriage (in fact, the husband already mortgaged this land use right for a bank) will be the common property of spouses after marriage. Unfortunately, the husband cannot pay the debt before the due date, the bank requests to dispose of the collateral which is land use right, but the husband disagrees and thinks that this is a common property of the spouses and not the husband's separate property. The bank has filed a lawsuit to the Court and requested the husband to repay the debt, the cancellation of the written agreement on the property regime of the couple and the disposal of the mortgaged property that is the land use right of the husband. The court must determine that the agreement to establish the property regime of husband and wife is invalid because of a serious violation of the bank's rights to the property mortgaged by the husband.

\footnotetext{
${ }^{24}$ Article 5 and 6 of the Joint Circular 01/2016/TTLT-TANDTC-VKSNDTC-BTP dated on January 6, 2016 which is a guideline on the implementation of the Law on Marriage and Family by the Chief Justice of the Supreme People's Court - Head of the Supreme People's Procuracy - Minister Issued by the Ministry of Justice.
} 
Fourth, it violates the regulations on the rights and obligations of spouses in meeting essential needs of the family. Once one party has a need to use and dispose of property to serve the essential needs of the family as well as themselves in daily life, there is no need for permission from the other party. The other party has no control, prohibiting the other party from using common property of husband and wife. Reagarding a number of cases related to property of great value, the law, however, requires that the common property disposition needs the consent of both parties.

Fifth, violation of regulations on transactions related to house which is the only residence of husband and wife. The establishment, execution and termination of house-related transactions that are spouses' sole residence must be agreed by both parties. If a house is privately owned by one party, the owner has the right to establish, perform or terminate transactions related to such property but must ensure accommodation for the other party. Whenever violation happens, the violated person or the guardian of the person whose rights and interests are infringed upon basic principles can submit a petition to the court. Procedures for reviewing the invalid agreement on the matrimonial property regime are specified in Article 5 of Joint Circular No. 01/2016/TTLTTANDTC-VKSNDTC-BTP. Specifically, the following agencies, organizations and individuals, in accordance with the civil procedure law, have the right to request the Court to declare that agreement on the matrimonial property regime is invalid due to the agreement. Regarding the property regime of husband and wife in the case specified in Clause 1, Article 50 of the Act on Marriage and Family: 1) The wife or husband has agreed on the property regime; 2) The violated person, the guardian of the person whose rights and interests are violated due to an agreement on the property regime of husband and wife. Regarding the order and procedures for settling a request, the court can declare a marital agreement being invalid; comply with the civil procedure law.

\section{Termination of the matrimonial agreement property regime}

\subsection{The termination of the agreement according to the parties' will}

The property regime under the agreement of the husband and wife will end when the husband and wife agree to terminate the property regime according to the agreement of the husband and wife. At this time, husband and wife will carry out procedures to confirm the termination of the property regime as agreed by them. Although the property regime under the agreement of husband and wife terminates, the marital relationship still exists and the statutory property regime will apply automatically since the property regime according to the agreement ends.

\subsection{The termination of the agreement according to law: dissolution and spouses' death}

Once the couple divorce or spouse's death regarding the Court's judgment declares this incident, the marriage relationship will end, the marital agreement regime will also terminates. In this case, if the prenuptial agreement regime is made, the settlement of property upon divorce will be applied according to this agreement and the properties not including in this agreement will be divided according to the provisions of law. Under the provisions of Clause 1, Article 59 of the 2014 Act on Marriage and Family on the settlement of the property relationship between 
husband and wife upon divorce, it mentioned that In the case of the legal property regime of husband and wife, the settlement settlement of property as agreed by the parties; If the agreement cannot be reached, at the request of wife, husband or husband and wife, the Court shall settle it according to Clauses 2, 3, 4 and 5 of this Article and in Articles 60, 61, 62, 63 and 64 of the Act on Marriage and Family'. If husband and wife have built the agreed property regime, but the contents of the agreement do not say anything about the way and conditions to divide property upon divorce, the Court will apply the division according to the statutory property regime to deal with. Similarly, illegal marriage cancellation also leads to termination of the marriage since the date the couple register their marriage and seems to have the same legal consequences of the property relationship as divorce. According to the provisions of Clause 6, Article 3 of the 2014 Act on Marriage and Family, 'Illegal marriage means that a man or woman has registered their marriage at a competent state agency, but one or both parties violate the marriage conditions according to the provisions of Article 8 of the 2014 Law'. Concerning the legal consequences of the marital property relationship, the agreement on the property regime cannot continue to valid after the marital relationship has been canceled by the Court, because the property relationship between husband and wife only exists when marriage is recognized. Once there is a prenuptial agreement without having foreseen regulations on the couple's null and void marriage, the regulations on marital property division when spouses divorce shall be applied to settle their property. In summary, how to resolve the property relationship between husband and wife when terminating the marriage relationship is one of the important issues that both partners often consider in their concurrence.

To conclude, the recognition of prenuptial agreement is an inevitable development of the marital property model by allowing the spouse to apply the prenuptial agreement or statutory marital property that depends on the spouses' will and desire. Thereby, the concept of the matrimonial agreement property is a term that has appeared since the French colonial period in Vietnam and is currently being re-regulated in the 2014 Act on Marriage and Family. In general, the establishment of prenuptial agreement needs to be in writing and notarized or authenticated. This is a regulation that has many similarities with the French and Hungarian Civil Code. However, at present, Vietnamese laws only recognise the form of the ante-nuptial agreement (also known as premarital agreement) but not yet the post marital agreement as in Hungarian law. The unrecognized post marital agreement should be considered in the Vietnamese marriage and family law because they may have a need to agree on property after marriage during the process of living together.

\section{Bibliography}

ATwood, Barbara: Marital Contracts and the Meaning of Marriage. Arizonal. Law Review 54/2012, 36-38.

BÙI MINH Hồng: Chế độ tài sản theo thỏa thuận của vợ chồng liên hệ từ pháp luật nước ngoài đến pháp luật Việt Nam [Property regime as agreed between husband and wife related from foreign law to Vietnamese law]. Journal of Law, No. 11/2009. https://thongtinphapluatdansu.edu.vn/2010/01/05/4322-2/ [accessed 2020/10/10].

Brown, Susan Vogt: The Enforcement of Marital Contracts in the United States, Great Britain, France and Quebec. Boston College International \& Comparative Law Review, Vol. 6, 475-507.

HÀ NHƯ Vinh: Chế độ hôn sản pháp định trong luật Việt Nam [The legal marriage regime in Vietnamese law]. Saigon 1967 
MAHAR, Heather: Why are there so few prenuptial agreements?. Harvard Law School John M. Olin Center for Law, Economics and Business Discussion Paper Series, Nr. 436, 1-38.

NguYen Thi My, Linh: The Impact of the French Colonial Law on the Development of Matrimonial Property Law in Vietnam. Díké 1/2019 65-82.

Nguyen Thi My, Linh: The Development of Matrimonial Property Law in Vietnam. Díké 2/2018 66-74. 